\title{
GOVERNANÇA DOS RECURSOS DE USO COMUM E DESENVOLVIMENTO TERRITORIAL SUSTENTÁVEL: ANÁLISE DOS ARRANJOS INSTITUCIONAIS DA PESCA NA GRANDE FLORIANÓPOLIS
}

\section{Elaine Cristina de Oliveira Menezes}

Pós-doutora em Administração

Professora do Curso de Gestão Pública

Universidade Federal do Paraná - Campus Litoral

eoliveira.menezes@gmail.com

\section{Maurício Roque Serva}

Pós-Doutorado - Universitat de València, UV, Espanha.

Professor do Programa de Pós-graduação em Administração

Universidade Federal de Santa Catarina mauserva@gmail.com

\section{Luciana Francisco de Abreu Ronconi}

Doutorado em Sociologia Política

Professora titular no Curso de Administração Pública

Universidade do Estado de Santa Catarina

lucianaronconi20@yahoo.com.br

\section{RESUMO}

Busca-se, por meio desse artigo, analisar os arranjos institucionais da pesca artesanal na Grande Florianópolis, com o intuito de compreender as possibilidades e os limites para a governança dos recursos de uso comum no contexto do desenvolvimento territorial sustentável da região. A pesquisa é de caráter qualitativo e valeu-se de estudo exploratório-descritivo e de entrevistas semiestruturadas com representantes da pesca artesanal da Grande Florianópolis. Os resultados apontaram que as comunidades de pesca estão buscando alternativas para fortalecer a governança local do setor. Entretanto, existem limites dessa governança, grande fragmentação das ações, conflitos e desarticulação dos atores envolvidos, bem como preocupação marginais quanto a reprodução dos estoques pesqueiros locais. Além disso, os atores que compõem os arranjos institucionais da pesca artesanal têm se organizado pouco no sentido de tornar essa atividade mais sustentável do ponto de vista social, econômico e ambiental.

Palavras-chave: Desenvolvimento territorial sustentável; Governança dos recursos de uso comum; Pesca artesanal.

\section{RESOURCES GOVERNANCE OF COMMOM USE AND SUSTAINABLE TERRITORIAL DEVELOPMENT: THE INSTITUTIONAL ARRANGEMENTS OF FISHING IN FLORIANÓPOLIS}

\section{ABSTRACT}

This paper analyzes the institutional arrangements of small-scale fishing, in order to understand the possibilities and limits for the resources governance of common use in the context of sustainable territorial development in Florianópolis and nearby cities. The research is qualitative and is based on an exploratory-descriptive study and semi-structured interviews with representatives of smallscale fishing in Florianópolis. The results showed that fishing communities are seeking for alternatives to strengthen local governance in the sector. There are, however, limits in the governance: fragmentation of actions, conflicts and disarticulation from the actors involved. We concluded that it is necessary to restructure the relationship between the local social actors and investment, by the public administration, in equipment and fishing gear and in collective learning.

Key words: Small-scale fishing; Resources Governance of common use; Sustainable territorial development. 


\section{INTRODUÇÃO}

Este artigo parte da concepção de desenvolvimento territorial sustentável (DTS), que é um conceito em construção, pautado no Ecodesenvolvimento, na gestão racional do ambiente e nos postulados do Desenvolvimento Territorial (Sachs, 1986; Vieira, 2006; Pecqueur, 2006). Essa concepção de desenvolvimento privilegia a formação de redes locais, a valorização dos recursos regionais e a gestão dos recursos naturais, de forma a privilegiar o desenvolvimento territorial. As estratégias propostas pelo desenvolvimento territorial sustentável se colocam como possibilidades e alternativas de sobrevivência das comunidades tradicionais, que se encontram à margem do modelo de produção globalizado, ao serem consideradas como uma problemática complexa (Morin, 1990). Toma-se como ponto de partida para a definição dos fundamentos do desenvolvimento territorial sustentável a degradação socioambiental e sua relação com estratégias de desenvolvimento de longo prazo, aspectos que são cruciais no atual contexto de trabalho dos pescadores artesanais, já que suas atividades estão inteiramente ligadas aos recursos naturais.

Alia-se a essa concepção as discussões sobre governança, buscando enfatizar aspectos da governança pública e territorial entendida como o sistema que determina o equilíbrio de poder entre todos os envolvidos: governantes, gestores, servidores, comunidade local e cidadãos, com vista a permitir que o bem comum prevaleça sobre os interesses de pessoas ou grupos (Pimentel et al, 2010; Kissler, Heideman, 2006). Na mesma linha de argumentação recuperamos o conceito de governança de recursos de uso comum, que resgata a necessidade de incluir à gestão de recursos comum a gestão tradicional e os sistemas contemporâneos de gestão comunitária de recursos comuns. As evidências empíricas, propostas pela literatura internacional e nacional sobre o tema, demonstram que as instituições voltadas para a utilização dos recursos naturais devem ser mais diversificadas e as interações entre sistemas sociais e naturais mais sensíveis aos feedbacks. Nesse sentido, é mais coerente reconhecer que as comunidades são capazes de resolver os problemas dos recursos comuns, já que são elas que lutam para encontrar soluções para seus problemas cotidianamente (Ostrom, 2010; Berkes, 2005; Sabourin, 2010).

Em se tratando da pesca, segmento abordado nesse estudo, no Brasil, a iniciativa do Governo Federal com a instituição do Ministério da Pesca e a fundação da Secretaria Especial de Aqüicultura e Pesca da Presidência da República, em 2003, criou expectativas para o avanço dessa atividade. Embora haja toda uma discussão sobre a evolução desse segmento, constata-se que a pesca artesanal, que possui grande relevância socioeconômica no litoral de Santa Catarina, vem sofrendo com a concorrência dos barcos de pesca (economicamente mais eficazes na pesca de alto-mar), tornando os pescadores assalariados. Além disso, com a introdução de uma infraestrutura turística, as famílias desses pescadores foram sendo absorvidas parcialmente dos setores de hospedagem e alimentação (Rais, 2010; MPA, 2011; Ouriques, 2007; Severo, 2008). Isso tudo sem considerar o próprio processo de urbanização desordenado do litoral e da degradação ambiental, que, juntos, vêm acarretando diversos malefícios, tanto à vida sustentável dos pescadores quanto à própria pesca artesanal, principalmente na região da Grande Florianópolis.

Nessa região, o trabalho na atividade turística vem tornando-se forte concorrente do trabalho na atividade da pesca artesanal, especialmente junto aos filhos de pescadores artesanais. Diante dessas constatações, onde estarão as comunidades pesqueiras do segmento artesanal da Grande Florianópolis? Como se configura a governança e os arranjos institucionais da pesca artesanal? Esses arranjos institucionais vêm contribuindo para o fortalecimento da pesca artesanal do ponto de vista socioambiental?

Conforme destacado as novas gerações de pescadores artesanais têm enfrentado diversos problemas na reprodução de suas atividades, inclusive no se refere à falta de organização e engajamento (Menezes, 2011; Joventino; Hohnsson; Lianza, 2013).

Diante do quadro descrito, este artigo tem o objetivo de analisar os mecanismos de regulação e governança da pesca artesanal com intuito de compreender os dilemas e as potencialidades dos arranjos institucionais atuais desse segmento em promover dinâmicas produtivas mais sustentáveis junto aos ecossistemas costeiros da Grande Florianópolis. Tal estudo justifica-se em razão de, por um lado, observarmos o aumento do debate acerca da governança no meio acadêmico e público e, por outro, de haver um gap entre esse debate e o efetivo movimento de participação e envolvimento da sociedade na gestão dos recursos de uso comum no Brasil e em Santa Catarina (pesca artesanal).

Esse artigo está estruturado em cinco seções. A primeira, diz respeito a apresentação da problemática do estudo. A segunda, trata da revisão de literatura acerca do tema desenvolvimento territorial sustentável e governança dos recursos de uso comum no contexto territorial. A terceira, diz respeito aos aspectos metodológicos da pesquisa, apresentando o tipo de pesquisa e os procedimentos de coleta e análise dos 
dados. A quarta, apresenta os principais resultados do estudo, destacando as características da governança da pesca artesanal nos municípios pesquisados, cooperação e reciprocidade na pesca artesanal da Grande Florianópolis e uma reflexão sobre a sua sustentabilidade socioambiental. Por fim, a quinta seção destaca as considerações finais do estudo.

\section{GOVERNANÇA DOS RECURSOS DE USO COMUM À LUZ DO DESENVOLVIMENTO TERRITORIAL SUSTENTÁVEL}

No âmbito da revisão de literatura, o conceito norteador e que foi o pano de fundo dessa pesquisa é o desenvolvimento territorial sustentável. Ele é concebido como um enfoque de planejamento e gestão, tendo como ponto de partida a problemática da degradação socioambiental e sua relação com estratégias de desenvolvimento de longo prazo (Sachs, 1986; 1992; 1993 E 2007; Vieira, 2006; Andion, 2007). É preciso destacar duas vertentes importantes para a definição do conceito de Desenvolvimento Territorial Sustentável, pautado epistemologicamente pelo enfoque da complexidade (Morin, 1990).

Por um lado, observamos a contribuição da abordagem territorial que trouxe inovações no campo socioeconômico com experiências largamente estudadas nos distritos industriais, sistemas produtivos locais, clusters, ambiente inovador, arranjos produtivos locais, entre outras denominações. Destacamos que cada uma dessas experiências demonstrou a contribuição de elementos novos para as dinâmicas produtivas e para a gestão das organizações, tais como a influência da cultura local; a possibilidade de sinergia, cooperação e competição; facilidade de acesso a mão de obra e conhecimento acumulado; difusão de inovação; possibilidade de regulação setorial conjunta, entre outros fatores (Becattini, 1999; Bagnasco, 1999; Benko, 2001; Courlet e Soulage, 1994; Courlet, 2001; Maillat, 1995; Marshall, 1982; Porter, 1999; Lemos, 2003; Lastres e Cassiolato, 2003). Sem contar as contribuições de estudos sobre a governança e seus reflexos sobre a eficiência coletiva (das empresas), bem como estudos que remetem a um conceito de governança mais amplo, apontando para um aumento do conjunto de atores (Bourque, 2000; Levésque, 2001; Schmitz, 1997a; Schmitz, 1997b).

Por outro lado, as contribuições das discussões sobre sustentabilidade também resgatam elementos imprescindíveis para a gestão das organizações na atualidade, principalmente quanto à prudência ecológica, satisfação das necessidades básicas e promoção da equidade, autonomia e redefinição do conceito de eficiência econômica que alia a produtividade com a minimização das perdas e reaproveitamento dos resíduos e dejetos como insumos para o sistema produtivo (Vieira, 2006; Sánchez, 2006; Vanclat, 2003). Na contribuição clássica de Ignacy Sachs (1993) há cinco dimensões do conceito: i) sustentabilidade social; ii) sustentabilidade econômica; iii) sustentabilidade ecológica iv) sustentabilidade espacial; v) sustentabilidade cultural. Assim, concluímos que a qualidade do meio biofísico tem reflexos na qualidade territorial e, consequentemente, na disponibilidade de insumos e de trabalhadores saudáveis e qualificados para os sistemas produtivos.

Além disso, ao resgatarmos as contribuições do desenvolvimento territorial, verificamos relativa importância do conceito de governança. Governança é um termo polissêmico e, embora tenha surgido no campo da ciência política, na interpretação de Pimentel et al (2010), surge no campo da economia como governança corporativa, em meados do século XX. Benko e Lipietz (2000) destacam, também, que, no campo socioeconômico e numa acepção restrita, a governança pode ser entendida como uma forma de organização interempresarial que se caracteriza por relações de poder que vão além do foco do mercado. A governança, para os autores supramencionados, nos remete às formas intermediárias de regulação, sejam elas, mercantis ou estatal, e que articulam interesses privados e público, aspectos econômicos e sociais, declarando-se sensíveis aos critérios de eficácia e equidade (Benko e Lipietz, 2000).

O que parece comum nas diferentes concepções de governança é a ampliação do campo de atores implicados, para além do campo da economia e dos mercados, demonstrando a "[...] interdependência desses atores, no processo de negociação e tomada de decisão e no suposto interesse e poder/influência que cada um deles tem neste processo" (Pimentel et al, 2010, p. 230). Nesse artigo compreende-se por governança um conjunto de sistemas de regulação intencional gerado por uma determinada organização social (Bourque, 2000). Para precisar essa definição, Bourque (2000, p. 10) adota o conceito de Hollingsworth e destaca que, [...] un système de gouvernance est donc defini comme la totalité des arrangements institucionnels [...] qui régulent les transactions à l'intérieur et à travers les frontières d'un système économique. 
A visão territorial da governança demonstra que ela é mantida por um conjunto de atores e instituições que não pertencem somente à esfera governamental, mas que se traduz pelas relações de interdependência existentes entre o Estado e as instituições associadas a uma ação coletiva específica. A governança é um processo institucional e organizacional de construção de mecanismos compatíveis com os diferentes modos de coordenação existentes entre atores sociais geograficamente próximos, para que possam resolver os problemas produtivos inéditos sentidos no território (Pecqueur, 2006), e para solucionarem problemas que transcendem os limites das relações econômicas. Na revisão de literatura há certo consenso de que as modalidades de coordenação econômica existentes são fruto da interação das pessoas, dos produtos, das convenções, das ações humanas e das formas de incerteza que são colocadas ao conjunto dos atores econômicos e que são por eles geridos. No âmbito da ciência econômica e da geografia não se pode negar a importância dos estudos de Benko e Lipietz (2000) para a gestão territorial.

Com efeito, para fazer avançar este debate, considera-se a reflexão de Bourque (2000) frutífera, visto que apresenta uma tipologia ampliada dos modos de governança, com o intuito de oferecer outros elementos além daqueles apresentados pelos modos tradicionais de coordenação das atividades econômicas. De maneira sintética, para Bourque (2000), esses tipos podem ser definidos da seguinte forma: i) governança mercantil; ii) governança hierárquica/corporativa; iii) governança estatal; iv) governança comunitária; v) e, governança em parceria/associativa. Na realidade, esses modos de governança se combinam, configurando uma dinâmica de hibridização. A governança que por ora nos interessa é a governança estatal ou pública, governança comunitária e a governança em parceria que compartilham elementos importantes para se pensar a economia social no âmbito da gestão dos recursos de uso comum.

Tendo como base a literatura sobre o tema, aliada à da pesca artesanal, optou-se, para fins didáticos, neste artigo, pela concepção de governança entendida como o conjunto de atores articulados com o fim de resolverem problemas comuns. Para tanto, concebe-se que a governança, nesse sentido, está organizada a partir de uma estrutura institucional pública e privada. Para fins analíticos, neste artigo, à essa estrutura institucional pública, denominar-se-á governança pública e se refere ao conjunto dos arranjos institucionais públicos (de atores que compõem o aparelho do Estado), órgãos públicos, ministérios e secretariais federais, estaduais e municipais, que contribuem para a organização e regulação da pesca artesanal. E à estrutura institucional privada, denomina-se governança privada, referindo-se ao conjunto dos arranjos institucionais de cunho privado (atores que não compõem o aparelho do Estado), entidades de classe, colônias de pesca, associações e cooperativas, dentre outros, concebemos como governança privada.

A evolução desse debate sobre o termo governança na esfera pública territorial e dos recursos comuns reforça a impressão de que a experimentação com novas modalidades de ação coletiva, norteadas pelo ideário do desenvolvimento territorial sustentável e outras correntes teóricas, vem se intensificando nos últimos tempos (Le Galès, 2004). No entanto, num contexto de globalização assimétrica a governança parece, ainda, fortemente condicionada pela ideologia economicista, colocando em segundo plano o enfrentamento dos dilemas colocados pela visão ecológica dos limites do crescimento material. Para aprofundar o debate sobre as formas de coordenação e o impacto sobre a sustentabilidade dos ecossistemas costeiros, a próxima seção aprofundará alguns elementos do conceito de governança dos recursos de uso comum.

\subsection{Governança de recursos de uso comum}

Para realizar uma análise mais profunda do conceito de governança, Ostrom (2010) parte do pressuposto de que as questões relativas a melhor maneira de gerir os recursos comuns não ocorre no meio acadêmico, mas no mundo político. Nesse sentido, buscar compreender a importância da combinação de atores no âmbito da gestão da pesca artesanal e da complexidade de avaliação dos seus fenômenos é fundamental para as análises sobre governança de recursos de uso comum. O recurso comum designa, de acordo com Ostrom (2010), um sistema de recursos suficientemente importante e de difícil exclusão dos beneficiários potenciais de acesso aos benefícios ligados a sua utilização.

Para Berkes (2005), baseado em Ostrom, Bromley e Feeny et al, os recursos de uso comum podem ser geridos sob quatro regimes de apropriação: i) livre acesso: "[...] significa a ausência de direitos de propriedade bem definidos. O acesso é livre e aberto a todos" (Berkes, 2005, p. 50); ii) propriedade privada: "[...] refere-se à situação na qual um indivíduo ou corporação tem o direito de excluir outros e de regulamentar o uso do recurso" (Berkes, 2005, p. 50); iii) propriedade estatal: "[...] significa que os direitos sobre o recurso constitui uma prerrogativa exclusiva do governo, que controla o acesso e regulamenta o uso"

Revista de Gestão Social e Ambiental - RGSA, São Paulo, v. 10, n. 1, p. 22-40, jan./abr. 2016. 
(Berkes, 2005, p. 50); iv) propriedade comunal ou comunitária: “[...] significa que o recurso é controlado por uma comunidade definida de usuários, que pode excluir outros usuários e regulamentar a utilização do recurso" (Berkes, 2005, p. 50). Conforme Berkes (2005), tais regimes podem ser hibridizados, ou seja, são tipos ideais, cujo controle tende a acontecer mediante combinações desses regimes.

Há um consenso na literatura, segundo Berkes (2005), de que o livre acesso tende a conduzir a ruína dos recursos de uso comum, conforme ilustrado na "tragédia dos comuns", descrita por Hadin. Portanto, é a propriedade privada, estatal e comunal que pode condicionar a utilização sustentável dos recursos. Além do livre acesso, a privatização dos recursos de uso comum também constitui um problema, pois muitos dos recursos são, por natureza, não exclusivos e inadequados para a apropriação privada. Conforme Berkes (2005), é o regime da propriedade comunal que oferece o mais diversificado conjunto de regulamentações. A dificuldade que acompanha o debate político atual dos recursos de uso comum está na definição de critérios adequados para o desempenho dos sistemas de recursos naturais sob diferentes regimes de apropriação.

Berkes (2005) destaca, ainda, que os trabalhos de Feeny, Berkes, McCay, Acheson foram baseados nos critérios de sustentabilidade ecológica, "[...] segundo o qual o recurso em questão deve ser usado sem comprometer a capacidade das gerações futuras de satisfazer suas necessidades" (Wced apud Berkes, 2005, p. 66), o que corrobora com o enfoque do desenvolvimento territorial sustentável. Entretanto, a solidariedade diacrônica representa, conforme o autor supracitado, apenas um dos critérios de uso dos recursos. É preciso compreender que o uso dos recursos deverá atender tanto o ponto de vista ecológico, quanto o ponto de vista econômico e social. Portanto, a análise deverá centrar-se simultaneamente nos seres humanos e nos recursos.

As questões que circundam a gestão dos recursos comuns são complexas e necessitam de uma reflexão interdisciplinar e ampliada. Quanto mais os recursos comuns se encontrarem próximos dos centros de atividades econômicas, o que tende a acontecer nos países mais desenvolvidos, mais chances de que a população da região, o valor da unidade de recurso e as atividades dos usuários vizinhos exerçam um efeito negativo sobre os resultados dos recursos comuns. Nesse sentido, os governos locais podem desempenhar um papel positivo colocando em ação equipamentos, reforçando a capacidade dos usuários locais de se engajar em uma concepção institucional eficaz. Esse papel positivo é diferente da centralização e do controle dos recursos comuns pelo Estado (Ostrom, 2010). Portanto, as análises de Ostrom (2010) demonstram que a conformação e utilização dos recursos de uso comum partem de uma escolha institucional, ou seja, escolha coletiva e constitucional, em que as regras e normas sejam construídas de maneira compartilhada e, portanto, internalizadas facilmente pelos usuários. Assim, faz-se necessário construir espaços de discussão e de aumento do acesso às informações (técnicas, legais e operacionais) tanto para os usuários do recurso comum, quanto para os gestores públicos e demais atores sociais (Vieira, 2006; Menezes, 2009; Menezes, 2011). Há, ainda, de se considerar o papel relevante da sociedade civil na gestão compartilhada dos recursos de uso comum.

Considera-se fundamental resgatar os saberes tradicionais para a gestão dos recursos de uso comum. Porém, tais saberes tradicionais, ampliados pelas inovações do conhecimento, deverão não somente permear o âmbito do planejamento público e legal, mas também transformar-se em ações em prol das comunidades tradicionais. A passagem do planejamento para a ação é fundamental na conformação da confiança e da reciprocidade no âmbito dos usuários dos recursos de uso comum e na ampliação do engajamento dos atores locais (Ostrom, 2010; Sabourin, 2010; Vieira, 2006; Morin, 1990).

A obra de Ostrom (1990) enfatiza a importância da cooperação e da reciprocidade e deixa claro que o funcionamento da ação coletiva não segue as hipóteses habituais da economia clássica. Para a autora supramencionada, não haveria cooperação sem reciprocidade. Assim, os atores, em geral, se esforçam para identificar outros atores envolvidos e os consideram como possíveis cooperadores (Sabourin, 2010). A questão da reciprocidade também é referenciada por Leff (2009), no que tange a gestão dos recursos comuns.

Tanto Ostrom (2010), quanto Leff (2009), ao analisarem dinâmicas produtivas comunitárias junto aos recursos comuns observaram a importância de elementos que já foram enfatizados pelos teóricos do desenvolvimento territorial (Becattini, 1999; Bagnasco, 1999; Benko, 2000; Courlet E Soulage, 1994; Courlet, 2001; Maillat, 1995). Nesse espectro analítico, Sabourin (2010), um estudioso do desenvolvimento territorial, corrobora com a ideia de Ostrom de que as políticas sejam adaptadas em razão da proporção ou da densidade de indivíduos reciprocitários ou egoístas e que tais políticas contemplem a inserção dos saberes tradicionais. Ostrom (2010) corrobora com a ideia de que as cooperativas e associações contribuem e apoiam à geração e à difusão da informação no âmbito das mudanças institucionais, ampliando a conformação das inovações nas regras e normas para gestão dos recursos comuns.

Importante frisar a necessidade de evolução desse debate, particularmente com ampliação da experimentação com novas modalidades de ação coletiva, norteadas pelo ideário do desenvolvimento 
territorial, da sustentabilidade e da governança dos recursos comuns (Sachs, 1986; Sachs, 2007; Vieira, 2006). Conforme Pecqueur (2006), como parte da ação conjunta de comunidades, tem-se a consolidação de relações de cooperação, reciprocidade e confiança que são promovidas principalmente pela proximidade geográfica, sociocultural e também de acesso e uso dos recursos comuns (Pecqueur, 2006; Ostrom, 2010; Sabourin, 2010). As reflexões sobre governança territorial ampliada e governança dos recursos de uso comum são férteis instrumentos para compreender as novas formas de organização que emergiram nesse início do século XXI, em meio às sociedades modernas, empresas e estruturas formais, bem como em meio às comunidades tradicionais. Apresenta-se, a seguir, os principais aspectos metodológicos da pesquisa.

\section{ASPECTOS METODOLÓGICOS}

Este estudo é do tipo empírico, valendo-se de um arcabouço teórico para norteá-lo. Caracteriza-se, também, como um estudo exploratório-descritivo. A pesquisa valeu-se, também, de uma abordagem qualitativa, sendo que o levantamento de informações incluiu fontes de dados primários e secundários. Os dados primários foram obtidos na pesquisa de campo pela aplicação de entrevistas semiestruturadas. Os dados secundários foram obtidos por meio de pesquisa documental e dados levantados em periódicos, revistas, jornais e demais publicações da região.

A seleção da região estudada deu-se em função do litoral catarinense ter relativa importância nas atividades pesqueiras. E é justamente o litoral central de Santa Catarina que recobre a quase totalidade dos municípios da Associação de Municípios da Grande Florianópolis. Verifica-se, pelos dados da Rais (2010), que os municípios da região da Grande Florianópolis que têm impacto sobre o número de empregos diretos gerados e estabelecimentos formais ligados à pesca são os municípios de Governador Celso Ramos e Florianópolis. Por essa razão, a pesquisa privilegiou o aprofundamento da dinâmica da pesca artesanal desses dois municípios. Quanto aos sujeitos de pesquisa, foram selecionados 25 representantes da atividade da pesca artesanal da Grande Florianópolis. Dentre eles: representantes das prefeituras municipais dos dois municípios, do Sindpesca, das comunidades pesqueiras dos dois municípios, de associações, das colônias de pescas e da federação das colônias de pesca, do MPA, do Ibama, do Ibama-Cepsul, do ICMBio e da Epagri.

A interpretação dos dados foi desenvolvida de acordo com a análise qualitativa e descritiva do conteúdo, correlacionando-se com o referencial teórico assumido.

\begin{tabular}{|c|c|l|l|}
\hline DIMENSÕES & $\begin{array}{c}\text { CONCEITOS } \\
\text { ESTRUTURANTES }\end{array}$ & $\begin{array}{l}\text { COMPONENTES DE COLETA } \\
\text { E ANÁLISE DOS DADOS }\end{array}$ & \multicolumn{1}{|c|}{ CAMPO TEÓRICO } \\
\hline Socioeconômica & $\begin{array}{l}\text { Caracterização do } \\
\text { setor }\end{array}$ & $\begin{array}{l}\text { História da região e da pesca } \\
\text { Estrutura o organização do } \\
\text { segmento de pesca artesanal } \\
\text { Números de pescadores artesanais }\end{array}$ & $\begin{array}{l}\text { Ibama (2010); MPA } \\
(2010) .\end{array}$ \\
\hline Sociopolítica & Governança & $\begin{array}{l}\text { Grau de cooperação entre os } \\
\text { pescadores e as instituições de } \\
\text { apoio ao setor. } \\
\text { Estratégias de inserção no } \\
\text { mercado } \\
\text { Mecanismos de regulação e } \\
\text { articulação interinstitucional }\end{array}$ & $\begin{array}{l}\text { Ostrom (2010); } \\
\text { Kissler, Heidemman } \\
\text { (2006); Thoenig e Duran } \\
(1996) ; \text { Milani (2008); } \\
\text { Berkes (2005); Leff (2009); } \\
\text { Bourque (2000); Pecqueur } \\
(2006) ; \text { Benko e Lipietz } \\
\text { (2000); Le Galès (2004). }\end{array}$ \\
\hline Socioambiental & Sustentabilidade & $\begin{array}{l}\text { Conflitos socioambientais } \\
\text { Extração do recurso segundo as } \\
\text { normas e políticas públicas }\end{array}$ & $\begin{array}{l}\text { Vieira (2006); Sachs } \\
\text { (1986); Sachs (2007). }\end{array}$ \\
\hline
\end{tabular}

Figura 1: Matriz teórico-metodológica da pesquisa

Fonte: Elaborado pelos autores

Para dar suporte a coleta e análise dos dados, elaborou-se uma matriz teórico-metodológica, conforme figura 1, cujos principais elementos analíticos estão dispostos dentro das três dimensões do DTS: a socioeconômica, que buscou avaliar e caracterizar a organização do segmento da pesca na região; a sociopolítica, que buscou identificar a estrutura dos modos de regulação pública e privada, bem como a 
estrutura da governança da pesca artesanal, com ênfase no conceito de governança pública territorial e governança dos recursos comuns; e a socioambiental, que identificou os principais conflitos entre preservação e exploração dos recursos naturais locais.

\section{A PESCA NA GRANDE FLORIANÓPOLIS: CARACTERÍSTICA DA PESCA ARTESANAL E REFLEXÕES DIANTE DA GOVERNANÇA TERRITORIAL}

Conforme Berkes et al (2006), há significativas diferenças entre as pescarias de grande escala e as de pequena escala e a de subsistência e tal distinção é relevante para compreender os arranjos institucionais da pesca artesanal. A primeira, está relacionada à pesca industrial e a segunda, à pesca artesanal. Por isso, para sintetizar essas características, Berkes et al (2006) distinguem a pesca de grande escala da de pequena escala. As características da pesca de grande escala apontam para um maior envolvimento da atividade com o mercado, sendo caracterizada como pesca comercial e industrial. Esse tipo de pescaria vale-se de barcos grandes e equipamentos com tecnologia sofisticada, em alguns casos com processamento do pescado a bordo. Já a pesca artesanal é uma pesca estável e de pequena escala, que mobiliza operadores individuais ou família ou grupo comunitário, cujas embarcações ou são de senhores ou um conjunto de proprietários ou são de propriedade do próprio pescador; o processamento do pescado limita-se a poucas etapas ou mesmo a nenhuma; as unidades são pequenas e a comercialização é, em geral, limitada à região ou ao local, no máximo em âmbito nacional.

Por meio da pesquisa de campo percebemos que a pesca na Grande Florianópolis surge com o processo de colonização açoriana, sendo uma atividade típica da região vinculada à cultura local.

Conforme Aggio (2008), diversos sítios arqueológicos catarinenses apontam para a importância da pesca no âmbito da sobrevivência e do desenvolvimento dos povos litorâneos do estado. Todavia, foi no final do século XVIII, a partir da colonização açoriana, que a agricultura foi sendo progressivamente abandonada para, então, na segunda metade do século XIX emergir a pesca de subsistência que exerceu uma importante função econômica e cultural. A consolidação da atividade pesqueira no estado de Santa Catarina deu-se, efetivamente, entre 1960 e 1940. De 1970 a 1990, a pesca passa a obter incentivos, principalmente, com a política de modernização e industrialização do Brasil que teve seu auge nas décadas de 1950 a 1970 e, após esse período, já na década de 1990, com a abertura de mercado houve um avanço significativo da pesca industrial. Na década de 1970, os incentivos estavam atrelados à política de industrialização do Brasil, já a década de 1980 foi um tanto esquecida. Em 1990, retomam-se as ações em prol da pesca. Ao mesmo tempo, observa-se, a partir dessa década, que houve, em todo o litoral catarinense, especialmente no litoral central, o aumento da especulação imobiliária, expansão das cidades e explosão do turismo de massa. Todos esses elementos da trajetória socioeconômica de Santa Catarina e da região da Grande Florianópolis acarretaram, nos últimos anos, uma pressão sobre a atividade da pesca artesanal.

Uma característica marcante da faixa litorânea central do Estado de Santa Catarina é o fato de existir um mosaico de áreas protegidas, composto por unidades de conservação, tais como a Reserva Biológica do Arvoredo, a Estação Ecológica de Carijós, o Parque Estadual da Serra do Tabuleiro e as Áreas de Proteção Ambiental de Anhatomirim e da Baleia Franca. Essas áreas possuem regras para seu acesso e utilização, sendo elas fiscalizadas pela Capitania dos Portos e Ibama, além de órgãos específicos para cada área protegida (Aggio, 2008). A produção pesqueira nessa região sofre, então, pressões de acesso ao recurso natural. Dessa forma, além das pressões de cunho demográfico e imobiliário, os pescadores artesanais têm enfrentado a pressão de acesso ao uso do recuso natural relacionada a reprodução dos estoques pesqueiros e à sobrevivência da pesca no médio e longo prazo.

Quanto às característica da região, observamos que a região centro-sul ainda apresenta incidência significativa da pesca artesanal. Porém, a atividade da pesca vem perdendo espaço para as atividades do turismo e da pesca industrial, mais rentáveis economicamente. Tal constatação demonstra a relevância de se levar em conta a sustentabilidade e viabilidade socioeconômica, conforme destacado por Sachs (1986). A evolução da pesca de 1995 a 2005 nos dois municípios pesquisados, totalizam 24 estabelecimentos na pesca e serviços relacionados e 18 estabelecimentos na aquicultura e serviços relacionados. Percebeu-se que, no ano de 2005, houve um aumento significativo, conforme Rais (2010). No caso da região pesquisada, esse salto deu-se, principalmente, em razão das pesquisas organizadas pela Universidade Federal de Santa Catarina e pela Epagri, que contribuíram para o avanço técnico dessa atividade, pensada, num primeiro momento, para ser uma alternativa à pesca artesanal. Essa tendência acompanha a evolução verificada no 
Brasil, conforme dados do Ibama (2009). Todo o avanço da aquicultura é parte de uma política do Governo Federal para ampliação do setor pesqueiro e é uma alternativa para os pescadores que estão encontrando dificuldade de acesso e volume ao recurso pesqueiro. Destaca-se que, ainda, não há muitos estudos que avaliem o impacto socioeconômico e ambiental dessa política na região pesquisada.

Embora tais dados sejam relevantes, na medida em que apresentam como está configurada a economia formal da pesca na Grande Florianópolis, é preciso reconhecer que a atividade pesqueira é mais ampla do que os dados formais apresentados (Rais, 2010). Isso ocorre em função da pesca artesanal ser uma atividade autônoma e, portanto, sem registros como estabelecimento. O registro de pescadores do Ministério da Pesca (2010) apresenta a situação do número de registros da pesca artesanal e industrial dos municípios pesquisados, e verifica-se, em Governador Celso Ramos, na pesca artesanal, 1.236 registros e na pesca industrial 1.056 registros, totalizando 2.292 registros no município (MPA, 2010). Já o município de Florianópolis possui 2.823 registros de pescadores artesanais, contra apenas 146 registros de pescadores industriais, totalizando 5.261 registros (MPA, 2010). Assim, percebemos que a pesca artesanal nos dois municípios totaliza 4.059 registros, frente a apenas 1.202 registros de pescadores industriais, o que confirma a vocação regional para a pesca artesanal (MPA, 2010). Os dados da FAO (2010) demonstram que o número de pescadores na América do Sul, de 1990 a 2006, vêm não apenas se estagnando como até decaindo. Esse fato é corroborado pelo presidente do Sindipesca, que afirma que o setor pesqueiro em Santa Catarina está em fase de estagnação (Menezes, 2011).

Quanto ao mercado de trabalho da pesca artesanal da região, percebemos que é, predominantemente, de homens em Florianópolis; em Governador Celso Ramos há um equilíbrio entre o sexo masculino e feminino (Menezes, 2011). Observamos, assim, que em Governador Celso Ramos, em razão da pesca predominante ser a do camarão, existe relação das atividades do pós-pesca com a mão de obra feminina, em decorrência da necessidade de mão de obra para os procedimentos de limpeza e descascar o camarão e pela necessidade de filetagem de peixes. Portanto, em Governador Celso Ramos percebemos que a mulher desempenha um papel importante nas atividades (Menezes, 2011). Diferentemente de Governador Celso Ramos, os dados do MPA (2010) demonstram que Florianópolis segue a tendência mundial da pesca, com a predominância de pessoas do gênero masculino (Menezes, 2011). Os registros dos pescadores demonstram que o gênero masculino ultrapassa em mais do que o dobro os registros do gênero feminino. Esses dados seguem a tendência do setor. Podemos perceber essa mesma configuração de gênero, ainda mais acentuado no âmbito da pesca industrial, tanto em Governador Celso Ramos, quanto em Florianópolis (Menezes, 2011).

Além disso, observamos, de uma maneira geral, tanto em Governador Celso Ramos, quanto em Florianópolis, que a faixa etária predominante dos pescadores artesanais e industriais é a de 41 a 60 anos, apresentando também concentração na faixa etária que vai de 21 a 40 anos (Menezes, 2011). No quadro da escolaridade, percebemos que em ambos os municípios há concentração maior de pescadores artesanais e industriais com altos índices de analfabetismo (Menezes, 2011). Todavia, os pescadores artesanais de Florianópolis já vêm apresentando maior escolaridade do que os de Governador Celso Ramos.

Quanto a cadeia produtiva da pesca, verificamos que ela é bastante regionalizada, pois as embarcações e os petrechos são fornecidos na região e no Estado de Santa Catarina. Ela inicia-se com os fornecedores de insumos. Nas questões relativas aos fornecedores, a pesquisa evidenciou, no período de 2010, que havia poucas dificuldades. Tal fato deu-se em razão de o Ministério da Pesca e Aquicultura (MPA) vir suprindo grande parte das demandas por financiamento dessa fase da cadeia produtiva, tendo a contribuição, em termos de suporte técnico, da Epagri (Menezes, 2011). Os programas do Governo Federal Pronaf-pesca, Revitaliza, Subsídio do óleo diesel, fábrica de gelo, entre outros, foram, relativamente, acessados pelos pescadores da região pesquisada. Conforme a opinião, quase que unânime, dos entrevistados, a criação do MPA alavancou o fomento dessa fase da cadeia produtiva, embora ainda haja diversos entraves de cunho burocrático (Menezes, 2011).

No quadro da captura, do processamento e da comercialização, há alguns entraves em termos de dependência do pescador artesanal acerca da figura do intermediário. Assim, verificamos que a etapa da cadeia produtiva mais problemática é a comercialização do pescado, pois a figura do atravessador traz divergência entre os pescadores quanto ao seu papel na configuração e organização do segmento artesanal. Muitos pescadores consideram a figura do intermediário necessária, bem como a parte da tradição da atividade pesqueira. Porém, existem posicionamentos críticos quanto ao papel do intermediário, já que o preço pago ao pescador é bastante inferior do que aquele que estão expostos nos mercados regionais. A seção, a seguir, apresenta as principais características da governança da pesca artesanal na região pesquisada. 


\subsection{Características da governança da pesca artesanal nos municípios pesquisados}

Em termos de governança pública no Brasil, o contexto da Política Nacional de Gerenciamento Costeiro é um ponto de apoio à gestão da pesca artesanal. A política pública costeira no Brasil foi caracterizada por Berkes et al (2006) como: um processo lento que tem acarretado desconfiança quanto a sua efetividade ao longo dos seus 17 anos de realização; não eficiente na integração institucional e setorial, por ser centralizadora e personalista; apresenta-se com pouco envolvimento dos atores sociais relevantes à sua implementação, como é o caso de pesquisadores das universidades costeiras.

Além disso, não há envolvimento efetivo e de longo prazo dos diferentes níveis governamentais, federal, estadual e municipal, no contexto de programas comuns de gerenciamento costeiro (Menezes, 2011; Berkes et al, 2006). Os programas em nível municipal são considerados importantes instrumentos na fixação da política pública, pois se aproximariam das práticas de manejo comunitário, tal fato é corroborado pela pesquisa de campo (Menezes, 2011). Todavia, são, ainda, incipientes as iniciativas. Os dados da pesquisa de campo corroboram com os achados de Berkes et al (2006), que consideram que a consolidação de uma política de gerenciamento costeiro municipal seria benéfica à pesca artesanal, pois poderia integrar, em atividades consorciadas, a pesca com outros setores, tais como o turismo responsável, além de garantir maior a conservação ambiental e o incremento de renda para as populações locais (Menezes, 2011). A fala, a seguir, expressa a falta de apoio no nível local.

[...] Falta apoio do governo de Santa Catarina; falta apoio da prefeitura; faltam políticas públicas locais; faltam oportunidades de trabalho para os jovens que migram para outras atividades. Imposições do Ministério da Pesca para licença dos barcos, etc. Há ausência de políticas públicas, de projetos, pois há verba federal (do ministério da pesca). As colônias estão desprovidas de informações (Representante do Sindipesca).

Constatou-se na pesquisa de campo que a pesca artesanal é permeada de um ambiente institucional bastante heterogêneo que envolve organizações de cunho privado e público. Há uma riqueza institucional significativa que, direta ou indiretamente, contribui para a gestão da pesca artesanal no Brasil e no Estado de Santa Catarina. A crítica a essas instituições está na pouca articulação e integração em prol de ações comuns (Menezes, 2011). Para compreender a estrutura no âmbito da esfera governamental verifica-se a existência das seguintes organizações: Ministério da Pesca e Aquicultura (atualmente extinto, mas que estava em vigor durante a pesquisa de campo) - representado pela Secretaria Regional de Aquicultura e Pesca - Seap regional no Estado de Santa Catarina; Ministério do Meio Ambiente - representado pelo Ibama, Ibama-Cepsul e ICMBio no estado de Santa Catarina; bancos públicos - representada pela Caixa Econômica Federal, Banco do Brasil etc.; Ministério do Trabalho - representado pelo Instituto Nacional do Seguro Social (Inss) e demais órgãos vinculados a promoção e gestão de benefícios para os pescadores artesanais.

O Ministério da Pesca e Aquicultura (MPA), conforme MPA (2011), é responsável pela implantação de uma política nacional pesqueira e aquícola, transformando esta atividade econômica em uma fonte sustentável de trabalho, renda e riqueza. Ou seja, o MPA realiza ações de fomento e estruturação do setor. Enquanto o Ministério da Pesca e Aquicultura é fomento, o Ministério do Meio Ambiente (MDA) tem a função de regulamentar e fiscalizar as atividades pesqueiras no Brasil e no Estado de Santa Catarina, por meio do Ibama, ICMBio etc., especialmente no que se refere aos estoques pesqueiros e às espécies mais ameaçadas. A fala a seguir corrobora com o quadro descrito acima quando constata que o MDA tem dado à pesca um cunho mais conservacionista à sua gestão, enquanto o MPA seria o fomento.

[...] O MMA tem enfoque conservacionista. Já o MPA foca a produção, captura, subsídios e abertura de milhões de alternativas. Temos na regulação do setor dois ministérios com objetivos diferentes. A gestão é compartilhada entre os dois ministérios. O MPA é fomento e tem a coordenação do setor, é influenciado pelos interesses do setor que é imediatista. $\mathrm{O}$ estado brasileiro é um estado desenvolvimentista, vê-se que o MMA tem menos poder de barganha. Existem na gestão da pesca 4 membros do MMA e 4 do MPA. O setor é forte e a influência do MPA acaba tendo mais poder de negociação (Representante do IBAMACepsul).

Assim, o ambiente institucional da pesca é permeado por diferentes atores e instituições. Entretanto, as nuances desses atores e instituições e as suas demandas, tornam confuso para o pescador artesanal o 
acesso aos diferentes órgãos públicos e entidades, especialmente, quando necessitam de acesso para a obtenção de direitos e regularização de deveres (Menezes, 2011)

Conforme destacado na metodologia apresentada, foram entrevistados 25 representantes de órgãos e entidades públicas e organizações da sociedade civil. O entrevistado representante da Epagri de Governador Celso Ramos faz uma crítica à estrutura e organização do setor, cujas instituições que coordenam, regulam, fomentam e fiscalizam são distintas e com objetivos distintos (Menezes, 2011). Cabe uma reflexão diante desse quadro institucional para que se possa discutir a possibilidade de simplificação das trajetórias percorridas pelas políticas e ações governamentais no âmbito da pesca artesanal. Ou seja, as escolhas institucionais, conforme definido por Ostrom (2010), mais especificamente escolhas constitucionais, parecem frágeis e pouco articuladas em termos de definição de normas compartilhadas.

Ainda no âmbito da esfera pública, observa-se que as instituições acabam por estar vinculadas ao Governo Federal e há, ainda, pouca articulação entre as esferas estaduais e municipais. As experiências estudadas, no Município de Governador Celso Ramos e de Florianópolis, demonstraram que, no âmbito da gestão da pesca estadual, a instituição que contribui com a organização do setor e que está vinculada ao governo do Estado de Santa Catarina é a Epagri. A Epagri realiza atividades de assessoria técnica, extensão e de levantamento de informações sobre o setor (Menezes, 2011).

No nível municipal nota-se que as ações do poder público são bastante incipientes (Menezes, 2011). Em Governador Celso Ramos, há uma secretaria de município totalmente voltada para a pesca. Em Florianópolis as ações estão vinculadas a Secretaria de Agricultura e Pesca. Entretanto, percebe-se grande preocupação por parte da esfera municipal em Governador Celso Ramos, visto que a pesca é uma atividade importante economicamente para o Município. Em Florianópolis, essa atividade encontra-se diluída com as demais, como é o caso do turismo, setor de tecnologia e da prestação de serviços. Em Governador Celso Ramos, a mobilização e consolidação da Secretaria da Pesca, embora para alguns seja um arranjo político para fortalecimento do governo que está no poder, foi positiva, no sentido de haver um reforço na busca de organização do setor no nível local (Menezes, 2011).

Nesse sentido, a linha de argumentação de Berkes et al (2006) corrobora com a pesquisa de campo realizada na região da Grande Florianópolis. No nível municipal, não são visíveis e evidentes os programas públicos que integram as ações da pesca. Além disso, pouco se fala em integração com os outros setores da economia regional e municipal. Em Florianópolis, há envolvimento dos pescadores artesanais no transporte de turista, para incremento de renda no verão. Porém, tais iniciativas são ainda esparsas e estão vinculadas ao turismo de massa e não há uma nova proposta de turismo comunitário e sustentável. Todavia, são experiências embrionárias e interessantes no que tange à organização e associação dos pescadores artesanais. Já em Governador Celso Ramos, esse tipo de ação associativa, integrando os barcos de pesca ao turismo não foi verificado (Menezes, 2011).

Complementando a avaliação das instituições da pesca artesanal, no âmbito da esfera nãogovernamental, existe a Confederação Brasileira de Pesca (CBP) e o Sindicato dos Pescadores de Santa Catarina (Sindpesca), que são instituições sem fins lucrativos. São essas duas instituições que representam os pescadores artesanais em Brasília. Conforme o Ibama (2010), no âmbito dessa esfera institucional privada, que possui grande representatividade de pescadores, existem as Colônias de Pesca, que, em Santa Catarina, compõem o quadro de 34 organizações. Essas colônias, por sua vez, estão diretamente ligadas à Federação de Pescadores Artesanais de Santa Catarina que, por sua vez, se integra à Confederação dos pescadores artesanais do Brasil. Em Florianópolis e Governador Celso Ramos, há apenas uma colônia em cada município.

Porém, essa rede institucional não possui grande legitimidade. As colônias já existem há algum tempo. Todavia, não há participação efetiva dos seus membros. Na percepção de alguns dos entrevistados, as relações existentes dentro das Colônias e instituições de apoio encontram-se permeadas por relações políticas, clientelistas e paternalistas (Galtung, 1996). No trabalho de campo, os representantes dos pescadores, expressaram que esse fato acarreta um descrédito em relação às políticas de desenvolvimento do setor, o que acaba refletindo-se no ambiente institucional (Menezes, 2011).

Os estudos de Aggio (2008) apontam que o pescador tem liberdade de escolher qual instituição o representará, se uma colônia de pesca $(\mathrm{CP})$ ou associação de pescadores. Embora haja possibilidade de escolha por parte dos pescadores, o avanço das atividades do Sindicato dos Pescadores acabou tornando-se um entrave na gestão institucional privada da pesca artesanal, na percepção de alguns dos entrevistados (Menezes, 2011). Durante a pesquisa de campo, observa-se certa concorrência entre a CP e o Sindpesca, o que corrobora com os resultados obtidos no trabalho de Aggio (2008), que já alertava para essa dinâmica competitiva. A presença da questão político partidária no seio da gestão e organização das instituições

Revista de Gestão Social e Ambiental - RGSA, São Paulo, v. 10, n. 1, p. 22-40, jan./abr. 2016. 
ligadas à pesca artesanal é significativa, especialmente no nível municipal. Tal fato é retratado pela fala a seguir:

Os municípios não participam em função do envolvimento político. A cada dois anos tem eleição, aí já viu. O prefeito é de um partido, a associação é de outro, o sindicato é de outro e a colônia é outro. Aí aparecem as rixas políticas (Representante da Federação das Colônias de Santa Catarina).

Portanto, a pesquisa realizada nos municípios de Florianópolis e Governador Celso Ramos reforçaram a hipótese de que há falta de integração entre os pescadores das Colônias, especialmente na conformação de medidas para melhorar a situação da categoria (Menezes, 2011). Conforme a percepção dos entrevistados, os pescadores artesanais têm dificuldades de trabalhar em conjunto, têm baixo grau de instrução e gostam de trabalhar sozinhos. Tais condições dificultam a organização do setor (Menezes, 2011). Sem contar que a dispersão entre os pontos de pesca no litoral brasileiro contribui para essa baixa integração entre os pescadores e diferentes comunidades de pescadores.

Por fim, há uma disputa por representação entre colônias e sindicato (Menezes, 2011). Além disso, no centro desse impasse está a disputa por obtenção de maior número de associados, pois maior número de associados significa um volume maior de recursos monetários entrando nos cofres dessas organizações, seja o sindicato ou a colônia. Assim, percebe-se que o curto prazo está muito presente na gestão privada da pesca artesanal, o que prejudica uma dinâmica mais sustentável da atividade pesqueira artesanal local (Menezes, 2011; Milani, 2008). A disputa por representação e a falta de legitimidade da mesma fica evidente na fala a seguir:

O Sindicato e a Colônia estão mais preocupados em organizar papeladas do que outra coisa. A polêmica do estaleiro OSX, a colônia foi representar. Nas reuniões, eles participaram como representante dos pescadores. A maioria das lideranças não são pescadores. Não são representantes legítimos, é uma questão mais política. Existem processos democráticos para eleição. Os pescadores líderes existentes, porém, não têm coragem para assumir a presidência da colônia. Tem o problema da questão da legitimidade e é por isso que muitos outros problemas surgem (Representante da Epagri Governador Celso Ramos).

Associações de pescadores não existem, um pouco por causa da discórdia na organização da categoria. Uma coisa eu entendo: ninguém está lutando para sair da zona de conforto, o que faria a diferença para a pesca. Deveria haver mais espaços de discussão. Tem aquele que gosta da colônia e detesta o sindicato (Representante Epagri Governador Celso Ramos).

O sistema cooperativista não funcionou aqui. Existe esse conceito na pesca que todos roubam, não deram certo. E o nosso pescador é avesso ao associativismo, somos individualistas. Fui da colônia durante 14 anos, ninguém quer assumir, não conseguem se juntar. Não acredito que haja disputa entre os pescadores (Representante da Prefeitura de Governador Celso Ramos 2).

O pescador é desunido. Eles têm que se unir, isso sempre foi preciso. Os pescadores têm relação de amizade, mas na hora de uma reunião ninguém vai. Eles acham que as reuniões iriam prejudicar (Representante pescadores de Governador Celso Ramos 1).

No entanto, alguns entrevistados apontam dinâmicas de solidariedade em situações de dificuldade, conforme expressado pelas falas a seguir:

Existe um individualismo, mas observando mais profundamente acho que não. Os pescadores não são inimigos. É uma categoria pacífica. Existe um embrião de solidariedade (Representante da Epagri Governador Celso Ramos).

Quando precisam, como foi o caso das licenças de pesca, 60 pescadores se reuniram para reivindicar as licenças. Nesses casos, abdicam do individual pelo coletivo (Representante da Secretaria Municipal de Pesca de Governador Celso Ramos).

A maioria das comunidades pesqueiras não tem rio para o acesso. Muitas têm que deixar na praia as embarcações e muitas vezes se unem para trazer a embarcação até a praia. A pesca artesanal não tem muita infraestrutura, tudo é muito manual e demanda muito esforço físico. Por isso, nessas horas eles se unem para trazerem os barcos até a praia e se ajudam.

Revista de Gestão Social e Ambiental - RGSA, São Paulo, v. 10, n. 1, p. 22-40, jan./abr. 2016. 
A atividade deixa os pescadores muito isolados, mas não descartam a possibilidade de ajuda. A articulação e cooperação é maior entre os membros da sua comunidade. O espírito solidário existe na dificuldade (Representante da Epagri Florianópolis).

As análises empreendidas por Ostrom (2010) destacam que a conformação e utilização dos recursos de uso comum são parte de uma escolha institucional, ou seja, escolha coletiva e constitucional, em que as regras e normas são construídas de maneira compartilhada e, portanto, internalizadas facilmente pelos usuários. Observa-se que as transformações econômicas, demográficas, culturais, sociais e políticas operadas a partir dos anos de 1990 vem modificando a estrutura da pesca artesanal na região e as regras e normas compartilhadas (sustentáveis) de uso do recurso comum.

Por isso, considera-se imprescindível a compreensão da governança do setor e as estratégias de atuação dos seus arranjos institucionais. Tem-se presente que, cabe, assim, aos diferentes atores e ao poder público construir espaços de discussão e de aumento do acesso às informações (técnicas, legais e operacionais). Assim, consideramos relevante a ampliação do acesso à informação e da transparência, tanto junto aos órgãos públicos, quanto junto às organizações da sociedade civil, para o aumento da confiança e reciprocidade entre os atores sociais envolvidos na atividade pesquisada.

\subsubsection{Cooperação e reciprocidade na pesca artesanal da Grande Florianópolis: fechando as amarras da análise sobre os arranjos institucionais}

No quadro da governança não-governamental, a estrutura e organização das instituições presentes na pesca artesanal demonstram a existência de associações e cooperativas na Grande Florianópolis, mas com pouca representatividade na região (Menezes, 2011). Dentre as poucas associações que se encontrou durante a pesquisa de campo, poucas são efetivamente atuantes. Dentre as mais atuantes tem-se as que coordenam o transporte de turistas e o transporte coletivo que são atividades alternativas à pesca e que ocorrem, principalmente, no Município de Florianópolis. Além disso, encontrou-se também algumas iniciativas relacionadas à maricultura. Entretanto, muitos pescadores já sentem necessidade de maior articulação e envolvimento da categoria para encontrar alternativas de viabilidade socioeconômica para a pesca artesanal.

Por isso, constituímos uma associação, pois tinha gente de fora da comunidade que já
estava realizando esse transporte e nós vimos que seria bom. Constituímos a associação.
Hoje não teríamos passeio para a Ilha do Campeche sem ela. Começou com 10 barcos.
Realizamos empréstimos e conseguimos aumentar para 28 barcos. A atividade dos
pescadores da Armação do Pântano do Sul são: pesca, principalmente no inverno, e turismo
(transporte de passageiros) como alternativa no verão, já que no verão não tem pesca.
Todos contribuem para a associação, hoje $10 \%$ do passeio fica para a associação e a
distribuição dos rendimentos ocorre de forma igualitária (independente de se ter
embarcações menores ou maiores) todos ganham a mesma coisa (Representante da
Associação de Transporte dos Pescadores da Armação do Pântano do Sul).

Todavia, a cultura do pescador artesanal é, conforme a opinião da maioria dos entrevistados, muito individualista (Menezes, 2011). O fato é que os pescadores usufruem de um recurso de uso comum, que não possui nem um regime de propriedade privada, nem um de livre acesso. Na verdade, o regime de acesso no Brasil tende a ser de propriedade pública, cuja regulação é estabelecida pela legislação, em contrapartida é dado ao pescador um direito de uso do recurso. Para muitos entrevistados, essa situação é uma das causas dessa dificuldade de consenso e confiança entre seus pares (Ostrom, 2010; Berkes et al, 2006). Nas falas dos próprios pescadores, observa-se que eles estão dispostos a ajuda mútua na dificuldade, interagem nas festas e eventos comunitários, mas não estão preparados para a organização conjunta de ações em prol do setor. Essa talvez seja a causa de muitas estatísticas de pesca artesanal serem questionáveis, em razão de o pescador não informar exatamente qual a quantidade pescada, por desconfiança e medo.

O sistema cooperativista não funcionou aqui. Existe esse conceito na pesca que todos roubam, e as experiências não deram certo. E o nosso pescador é avesso ao associativismo, somos individualistas. Fui da colônia durante 14 anos, ninguém quer assumir, não conseguem se juntar. Não acredito que haja disputa entre os pescadores, mas eles são individualistas (Representante Prefeitura de Governador Celso Ramos 1). 
Esse tipo de organização não funciona, pois o atravessador não deixa isso operar. Seria preciso uma grande cooperativa para vender e comprar insumos (Representante do Sindipesca).

Percebemos, também, que as iniciativas voltadas para a coordenação da dinâmica interorganizacional permanecem nas mãos de poucas pessoas, especialmente no que refere às lideranças comunitárias. Esse fato se dá em razão, por um lado, da falta de interesse dos pescadores de participação da gestão setorial e territorial, e, por outro, do peso das relações político-partidárias existentes. Dessa forma, a pesquisa reforçou a impressão de que há carência de ações em prol da qualidade do meio ambiente e da organização do setor. $\mathrm{O}$ enfoque econômico clássico das instituições, intervenções e administrações públicas é predominante, mostrando-se insuficiente para um enfrentamento consequente dos problemas de gestão ambiental integrada e participativa no longo prazo (Godard, 2000).

Portanto, de uma maneira geral, dentre os principais problemas das organizações que representam o setor tem-se: patrimonialismo (Faoro, 2001; Godard, 2000); falta de articulação entre diretorias e usuários e a própria falta de articulação do pescador. Tal fato constata-se em razão das análises realizadas na seção anterior em que a governança institucional nos municípios pesquisados, tanto pública, quanto privada, é permeada pelo patrimonialismo em detrimento de dinâmicas mais autônomas de desenvolvimento (Faoro, 2001; Godard, 2000; Menezes; Vieira, 2010).

Quando confrontados com aspectos econômicos, os entrevistados tendem a enfatizar interesses individuais em detrimento dos interesses coletivos. Todavia, observa-se que existem, ainda que embrionariamente, relações de proximidade e reciprocidade entre os pescadores.

De uma maneira geral não vejo muitas situações de cooperação. Existe principalmente quando precisam de ajuda, mas não é frequente. Uma coisa curiosa é que em Florianópolis existem os pontos casados. Ou seja, numa mesma praia podem existir três pontos de pesca e eles são próximos. Quando a pesca fica entre o ponto de pesca do pescador X e Y, os três pescadores auxiliam o pescador $\mathrm{X}$ na pesca e quando eles voltam da pescaria dividem a pescaria de maneira igual entre os três pescadores. Essa situação é uma situação de cooperação que chama atenção em Florianópolis. Porém, o comum é que cada um pesque o seu, esconda suas artimanhas para pescar e exista competitividade. Em situações de dificuldades como quebra de barco, problemas de saúde, etc., eles se ajudam (Representante da Epagri de Florianópolis).

Dessa forma, pode-se verificar que o pescador não é totalmente isolado da sua comunidade e dos seus pares, embora encontre dificuldades de cooperação e engajamento, movimento que ocorre em diferentes segmentos da sociedade contemporânea (Putnam, 2002). Tal constatação também é corroborada pela pesquisa realizada por Rebouças (2008) no núcleo de pescadores artesanais de Garopaba. Nesse sentido, constata-se que há embriões do cooperativismo, associativismo e engajamento nas comunidades pesqueiras, mas ele é pouco expressivo, carecendo de mais estudos para reconhecer quais são os reais entraves ao engajamento mútuo no contexto da pesca artesanal da região pesquisada.

Não obstante, a pesquisa de campo demonstrou que a experiência do associativismo tende a envolver muito mais os pescadores. Embora, eles se intitulem individualistas, não se pode furtar de esclarecer que no associativismo e cooperativismo existem conflitos. Ademais, o conflito é parte do processo de negociação e de tomada de decisão conjunta e não, necessariamente, ele é negativo. Ele é parte constitutiva das sociedades democráticas. Embora as relações de cooperação sejam, ainda, tênues, no que tange à organização do setor, existem relações de solidariedade e cooperação que vão além daquelas vinculadas à categoria profissional. As relações de cooperação que se estabelecem são as comunitárias, de parentesco, respeito e amizade (Courlet e Soulage, 1994; Sabourin, 2010; Ostrom, 2010).

Como argumenta Ostrom (1990), quando um pescador realiza ações coletivamente seus ganhos são maiores do que quando ele age individualmente. $O$ grande entrave do maior envolvimento dos pescadores é que a racionalidade do curto prazo é ainda predominante. Além disso, há necessidade de ampliar e aproximar o pensamento ecológico tradicional à luz das transformações da sociedade contemporânea, incentivando os momentos de formação e informação em prol de mecanismos socioeconômicos mais autônomos e em prol de novas formas de usufruir dos recursos de uso comum, num contexto de degradação e escassez dos estoques pesqueiros.

Tendo como base as entrevistas, constata-se que as ações dos Ministérios da Pesca - MPA e Meio Ambiente - MDA não estavam sincronizadas e isso se reflete na operacionalização da pesca na região. Isto é, 
o fato dos Ministérios serem regidos por objetivos diferentes, causou entraves na própria gestão pública do setor que se reflete em ações confusas para o pescador em torno da disputa por recursos públicos (Menezes, 2011).

Por meio das análises descritas até o presente momento, observa-se que a governança da pesca artesanal na Grande Florianópolis, mais especificamente em Florianópolis e Governador Celso Ramos, possui questões emblemáticas semelhantes e divergentes. É possível perceber que o fato de Florianópolis ser a capital do Estado e ser sede de uma economia baseada no turismo, na tecnologia e no serviço, os pescadores artesanais já vem encontrando alternativas socioeconômicas para sua subsistência e de suas famílias fora da pesca, denotando uma certa "multifuncionalidade no âmbito familiar". Em Governador Celso Ramos, percebe-se que a economia local é muito mais dependente da pesca do que a de Florianópolis.

Ainda que no nível federal, a governança pública seja semelhante para os dois Municípios, a governança pública municipal em Governador Celso Ramos dá evidências de maior organização, pela própria dependência econômica do município frente ao segmento da pesca. É impreterível destacar que as relações existentes entre os pescadores e o Governo Federal perpassam por demandas de acesso ao crédito, aos cursos de formação e à capacitação e orientação, à regulamentação e à fiscalização da atividade pesqueira. No âmbito federal, há uma gama de órgãos e Ministérios responsáveis pela coordenação de ações para a pesca artesanal, o que significa certo entrave no âmbito da governança pública. Contudo, a criação do MPA aproximou o pescador do Governo Federal. Porém, há críticas à burocracia demandada para acesso aos programas veiculados pelo nível federal. Um dos pescadores expressa que "Quanto ao MPA há uma burocracia. Para financiamento precisamos de três pessoas como avalista. Fazem, mas dificultam muito" (Representante dos pescadores da Armação do Pântano do Sul 1).

Em razão do que foi mencionado, reforça-se o fato de que a conformação do MPA, como órgão federal para gerir a pesca no Brasil, trouxe alguns benefícios para os pescadores. Entretanto, do ponto de vista da estrutura do MPA, nota-se que ela é enxuta, com poucos funcionários e pouca capilaridade no interior do Estado. Além disso, a governança pública, ainda, é permeada por forte apelo aos aparatos jurídico-legais e financeiros, o que reforça o caráter burocrático e tecnocrático do Estado (Duran; Thoening, 1996). Esse retrato de uma gestão pública arraigada aos antigos sistemas de gestão é evidente no Brasil e na região da Grande Florianópolis. No âmbito da gestão pública, a participação social poderia estar diretamente articulada na formulação e implementação de políticas públicas, com o objetivo de compartilhamento de responsabilidade na tomada de decisão política e de construção de consensos sobre os conteúdos da política pública local (Milani, 2008).

Além de tais constatações, quando se analisam as relações entre pescadores e intermediários, observa-se que há uma forte ligação entre ambos e que essa relação vai além da atividade de compra e venda do pescado. Há, claramente, um vínculo de parentesco e amizade que chega a promover certa dependência do pescador ao atravessador e há resistência às mudanças na estrutura de venda e comercialização dentro das comunidades. Esse fato ficou bastante evidente durante a pesquisa de campo em Governador Celso Ramos. Em Florianópolis, percebem-se falas mais críticas em relação à dependência do atravessador pelo pescador, no sentido de necessidade de mudança da estrutura vigente. Enquanto em Governador Celso Ramos esse sistema é, de certa forma, legitimado pela relação de parentesco e amizade existente entre pescadores e intermediários, que, em muitos casos, é o próprio pescador, em Florianópolis esse sistema é criticado, apontando-se para outras alternativas de comercialização, como, por exemplo, um centro de recebimento e comercialização do pescado (Menezes, 2011).

É forçoso salientar que a relação entre associações e os pescadores que participam das mesmas é bastante tênue. As associações mais representativas identificadas, conforme representante da Epagri de Florianópolis são: a da Costa da Lagoa, a Cooperativa de transporte da Lagoa da Conceição e a Associação da Armação do Pântano do Sul, em que foram realizadas visitas. As principais atividades dessas organizações estão voltadas à complementação de renda às famílias dos pescadores artesanais por meio do transporte coletivo e de turistas. No entanto, essas associações contribuem, também, para a organização dos pescadores dessas comunidades. Para os pescadores que fazem parte das associações, ficou evidente a importância dessa alternativa de trabalho e renda num período do ano com poucas opções de captura pela pesca artesanal. Tal fato é corroborado por estudos da década de 1998 que resgatam a história da pequena pesca marítima, conforme destacado a seguir:

[...] a própria desestruturação interna de comunidades tradicionais, ou a intensificação das diferenças sociais em seu interior, concorriam pelo outro lado — isto é, pelo lado da oferta - para a emergência de uma mão-de-obra para ser explorada pelo setor empresarial na 
pesca. O caso da migração de muitos pescadores catarinenses para a pesca embarcada de Santos ou do Rio Grande do Sul, como já sublinhamos anteriormente, parece exemplar neste sentido (Silva, 1998, p. 225).

Além disso, há dificuldades na gestão dessas organizações de cunho social e privado, de acordo com o presidente da Associação de Transporte dos Pescadores da Armação do Pântano do Sul. As causas dessas dificuldades têm como centro o pouco engajamento e envolvimento com as atividades associativas, como destacado em diversas falas anteriormente. $\mathrm{O}$ fato de o pescador estar focado na captura acarreta resistência na promoção de atividades de organização de documentação, comercialização e mesmo participação e envolvimento das atividades associativas (Menezes, 2011). Tais aspectos são corroborados pela fala do representante da Associação de Transporte dos Pescadores da Armação do Pântano do Sul:

O pescador prima pela liberdade. Faz parte da cultura dele. A pesca é uma caça ao peixe, é quase como o cara que joga, não sabe com que ele vai voltar. Para se organizar não encaixa no dia a dia dele. A cabeça dele está voltada para o mar. Para o pescador se organizar é coisa nova é algo novo. Há duas vertentes de trabalho na pesca que devem ser organizadas: i) o processo de captura: essa é a profissão dele e quando chega em terra esse processo se encerra; ii) a documentação e organização: organização de documentação e tomada de decisão. A comercialização fica no meio dessas duas funções. Então precisamos do grupo que captura e do grupo que faz a organização. Diversificar a renda é uma alternativa, tendo como alternativa o turismo, a pesca: piscicultura e aquicultura, mas é algo novo (Representante da Associação de Pescadores da Armação do Pântano do Sul).

Diante das constatações da pesquisa de campo, verificamos pouco fortalecimento das instituições sociais e privada (colônias, sindicatos, associações, cooperativas, etc.) e a frágil participação social e o engajamento na tomada de decisão por parte dos pescadores artesanais. Tal fato contribui para que a gestão da pesca artesanal reproduza alguns vícios da cultura política baseada no clientelismo e patrimonialismo (Faoro, 2001; Godard, 2000). Isso não significa que não haja nenhum tipo de mecanismo de cooperação entre pescadores e instituições de apoio. Tal fato é corroborado por Rebouças (2008, p. 136)

Os comportamentos cooperativos entre os usuários do mar e seus recursos, de maneira geral, são menos expressivos do que os comportamentos conflituosos (ou nem tão evidentes). Foi possível perceber que no dia a dia da pesca artesanal existem diversos momentos de cooperação técnica e de expressões de solidariedade entre pescadores[...] Existem também laços antigos de respeito e solidariedade entre os núcleos.

Constata-se, assim, que a reprodução de sistemas complexos de gestão, a falta de informação e processos de aprendizagem coletiva e o agravamento dos problemas de natureza socioambientais reforçam o quadro pouco estruturado da governança da pesca artesanal na Grande Florianópolis.

À luz das reflexões de Courlet e Soulage (1994), reforça-se a hipótese segundo a qual, nas sociedades contemporâneas, as relações de reciprocidade estão presentes, por exemplo, na família, nos grupos de amigos e nos espaços de intercâmbio comunitário (Courlet e Soulage, 1994; Courlet, 2001). Observa-se que o déficit de credibilidade da rede de instituições locais, regionais e nacionais junto aos pescadores pode ter como fundamento a perda de engajamento cívico e comunitário. Todavia, dentre as potencialidades proeminentes da pesca artesanal, está o fortalecimento das redes comunitárias já existentes e apoio na ampliação dessas redes comunitárias. E, no quadro dos seus limites, está a dificuldade de engajamento cívico e a tendência à escassez dos estoques pesqueiros. Além disso, a governança desse setor reforça a ideia de que a pesca artesanal está desprovida de investimento em aprendizagem coletiva e em informação, o que a torna ainda mais frágil no contexto econômico atual de pressões econômicas globais.

\section{CONSIDERAÇÕES FINAIS}

Diante do quadro apresentado, verificamos que o conceito de desenvolvimento territorial sustentável, que deu suporte à pesquisa de campo, se traduz como um enfoque de planejamento e gestão territorial centrado na elaboração de estratégias que integram as diferentes dimensões, socioeconômicas, sociopolíticas e socioambientais do desenvolvimento. Articulá-lo com as questões que envolvem a governança, torna-se

Revista de Gestão Social e Ambiental - RGSA, São Paulo, v. 10, n. 1, p. 22-40, jan./abr. 2016. 
importante para análise da pesca artesanal neste início do século XXI. Recuperamos, assim, o conceito de governança de recursos de uso comum, que destaca a necessidade de incluir à gestão de recursos comum a gestão tradicional e os sistemas contemporâneos de gestão comunitária dos recursos comuns. O trabalho de campo corrobora com as evidências apresentadas nos estudos de Ostrom (2010) que demonstram que as instituições voltadas para a utilização dos recursos naturais devem ser mais diversificadas e as interações entre sistemas sociais e naturais mais sensíveis aos feedbacks.

As comunidades, embora apresentem limites de organização, devem ser reconhecidas como capazes de resolver os problemas dos recursos comuns, já que são elas que lutam para encontrar soluções para seus problemas cotidianamente (Ostrom, 2010; Berkes, 2005; Sabourin, 2010). Assim, diante do contexto da pesca artesanal que sofre pressões da indústria pesqueira, especulação imobiliária, turismo de massa e desarticulação interna, os pescadores artesanais poderiam encontram alternativas coletivas para enfrentar o efeito da perda de renda, o desemprego e a exclusão social.

A compreensão da governança da pesca emerge, assim, como uma alternativa para os problemas atuais que envolvem a pesca artesanal e a sustentabilidade territorial e socioambiental da região pesquisada. No trabalho de campo, observou-se que as comunidades pesqueiras do segmento artesanal da Grande Florianópolis encontram-se em algumas regiões do litoral central. Dentre os municípios pesquisados, Governador Celso Ramos e Florianópolis, apresentam comunidades tradicionais, ainda que pressionadas pela expansão urbana e turística.

O objetivo inicialmente estabelecido foi o de analisar os mecanismos de regulação e governança da pesca artesanal com intuito de compreender os dilemas e as potencialidades dos arranjos institucionais atuais desse segmento, em promover dinâmicas produtivas mais sustentáveis junto aos ecossistemas costeiros da Grande Florianópolis. A pesquisa de campo identificou que os arranjos institucionais são organizados a partir de instituições (governança) públicas e privadas.

No que tange à governança pública, compreendida como o conjunto de órgãos e entidades relacionadas ao aparelho do Estado, verifica-se que a sua dinâmica é, ainda, pouco compreendida pelos pescadores artesanais. Muitos dos pescadores não compreendem bem as normas e regras de uso dos recursos estabelecidas pelo Estado.

No que se refere à análise da governança privada, composta pelas organizações da sociedade civil relacionadas ao segmento pesqueiro, tais como associações, sindicatos e cooperativas, percebemos, no decorrer da pesquisa de campo, que ela é composta por algumas poucas organizações com dificuldade de compartilhamento de informações e ações. A pesquisa de campo demonstrou que o estímulo e fortalecimento das relações de cooperação poderiam contribuir para aproximação dos pescadores, reduzindo o isolamento e a tensão existente entre eles e as instituições de apoio, bem como reforçando a confiança existente entre eles (Ostrom, 2010). Além disso, parte-se da hipótese de que o estímulo às relações de confiança poderia promover maior sustentabilidade dos ecossistemas costeiros.

Verifica-se que há, embrionáriamente instituições não-governamentais que poderiam resgatar a ação coletiva das comunidades e promover espaços de diálogo e ampliação da confiança e reciprocidade dos atores locais, tais como associações de pescadores e colônias de pesca. Todavia, os traços de uma cultura política patrimonialista, tanto na governança pública, quanto na governança privada, dificultam a ação coletiva da pesca artesanal (Faoro, 2001; Godard, 2000). Há necessidade de aumento da transparência junto às organizações que são responsáveis pela gestão pública e pelas organizações da sociedade civil, com o intuito de gerar maior credibilidade e confiança a essas instituições.

Constatou-se uma preocupação que permeia todos esses espaços da governança da pesca artesanal, tanto pública, quanto privada, particularmente quanto aos problemas dos estoques pesqueiros. Nesse sentido, é preciso aprimorar as políticas de longo prazo voltadas para a ampliação do conhecimento sobre o ordenamento da pesca e dos recursos naturais e promover o estímulo à ampliação da autonomia e empoderamento dessas comunidades. Em se tratando da problemática da pesca artesanal, não se pode negligenciar a necessidade de transformação dos aspectos teórico-metodológicos tradicionais para a compreensão desse campo de estudo, particularmente no campo da gestão pública.

Portanto, verificamos que o processo de constituição e as macrodiretrizes das organizações que compõem o segmento da pesca artesanal não estão contribuindo significativamente para o desenvolvimento de ações em prol das comunidades, do meio ambiente e do território. Dessa forma, as políticas públicas poderiam ser orientadas no sentido do fortalecimento da formação de redes solidárias, pois são essas redes que poderão ajustar as políticas públicas para o setor, bem como definir melhores estratégias para enfrentamento dos problemas da pesca artesanal na região da Grande Florianópolis. No que tange à sustentabilidade socioambiental, consideramos que o pescador artesanal é, em certa medida, consciente da 
sua relação com a natureza e com os problemas que ele pode causar com a sobrepesca. Porém, a dificuldade de articulação entre o conhecimento ecológico local e o científico e a dificuldade de fiscalização efetiva do uso do recurso comum (pela comunidade e pela gestão pública), vem acarretando a perda dos estoques pesqueiros e tornando incerto o futuro da pesca artesanal na região. Por isso, sugere-se a ampliação de estudos acadêmicos sobre a problemática da pesca artesanal, sua sustentabilidade socioeconômica e socioambiental na região pesquisada.

\section{REFERÊNCIAS}

Aggio, R.B. M.(2008) Pesca artesanal na Baía Norte de Florianópolis: capturas, esforço de pesca, problemática e possíveis soluções. Monografia (Graduação em Ciências Biológicas) - Universidade Federal de Santa Catarina. Florianópolis.

Andion, M. C.(2007) Atuação das ONGs nas dinâmicas de desenvolvimento territorial sustentável no meio rural de Santa Catarina: os casos da APACO, do Centro Vianei de Educação Popular e da Agreco. Florianópolis, 2007. 385 f. (Tese de Doutorado, Programa Interdisciplinar em Ciências Humanas), UFSC, Florianópolis.

Becattini, G.(1999) Os distritos industriais na Itália. In: Cocco, G., Urani, A., Galvão, A. P. Empresários e empregos nos novos territórios produtivos: o caso da Terceira Itália. Rio de Janeiro: DP\&A.

Bagnasco, A.(1999) Desenvolvimento regional, sociedade local e economia difusa. In: Cocco, G., Urani, A., Galvão, A.P. Empresários e empregos nos novos territórios produtivos: o caso da Terceira Itália. Rio de Janeiro: DP\&A.

Benko, G., Lipietz, A.(2000) La richesse des régions: la nouvelle géographie socio-économique. Paris: Économie en Liberté.

Benko, G.(2001) A recomposição dos espaços. Revista Internacional de Desenvolvimento Local. 1(2), mar.

Berkes, F. et al.(2006) Gestão da pesca de pequena escala: diretrizes e métodos alternativos. Kalikoski, D. [org]. Rio Grande: Editora da Furg.

Berkes, F.(2005) Sistemas sociais, sistemas ecológicos e direitos de apropriação de recursos naturais. In: Vieira, P. F., Berkes, F., Seixas, C. Gestão integrada e participativa de recursos naturais: conceitos, métodos e experiências. Florianópolis: Aped.

Bourque, G.L.(2000) De l'ancienne à la nouvelle économie: un processus de modernisation sociale de l'industrie. Cahiers du Crises. Coleção Working Papers, n. ET0006. Mars.

Courlet, C., Soulage, B.(1994) Industrie, territoires et politiques publiques. Paris: L'Harmattan. . (2001) Territoires et régions, les grands oubliés du developpement économique. Paris: L'Harmattan.

Duran, P., Thoening, J-C.(1996) L'État et la gestion publique territoriale. In: Revue Française de Science Politique. 46e année(4).

FAO. (2010)La situation mondiale des pêches et de l'aquaculture. Roma : Organisation des Nations Unies pour l'alimentation et l'agriculture, 2008. Recuperado em 17 ago. 2010, de : <ftp://ftp.fao.org/docrep/fao/011/i0250f/i0250f.pdf>.

Faoro, R.(2001) Os donos do poder: formação do patronato político brasileiro. São Paulo: Globo.

Galtung, J.(1996) Cultural peace: some characteristics. In: Unesco (Org.). From a culture of violence to a culture of peace. Paris: Unesco, 75-92.

Godard, O.(2000) A gestão integrada dos recursos naturais e do meio ambiente: conceitos, instituições e desafios de legitimação. In : Vieira, P. F., Weber, J (Orgs.). Gestão de recursos naturais renováveis e desenvolvimento. Novos desafios para as ciências ambientais. São Paulo: Cortez, 201-266.

Ibama.(2009) Produção pesqueira e Aquícola: estatística 2008-2009. Brasília: MPA. 
Joventino, F. K. P., Johnsson, R. M. F., Lianza, S.(2013) Pesca artesanal na baía de Ilha Grande, no Rio de Janeiro: conflitos com unidades de conservação e novas possibilidades de gestão. Revista Política \& Sociedade, 12(23), 159-152, jan/abr.

Kissler, L., Heidemann, F.G.(2006) Governança pública: novo modelo regulatório para as relações entre Estado, mercado e sociedade? In: Revista de Administração Pública. Rio de Janeiro: FGV, 40, maio/jun.

Lastres, H. M. M., Cassiolato, J.E.(2003) Sistemas de inovação e arranjos produtivos locais: novas estratégias para promover a geração, aquisição e difusão de conhecimento. Revista Centro de Ciências Administrativas: Fortaleza: [s.n.], 9(2), 189-195, dez.

Leff, E. (2009) Ecologia, capital e cultura: a territorialização da racionalidade ambiental. Vozes: Petrópolis.

Le Galès, P.(2004) À chaque ville sa gouvernance. Auxerre: Sciences Humaines. Hors-série, (44).

Lemos, C.(2003) Micro, pequenas e médias empresas no Brasil: novos requerimentos de políticas para a promoção de sistemas produtivos locais. Rio de Janeiro, 2003. 269f. (Tese de Doutorado, Programa de Pós Graduação em Engenharia de Produção). UFRJ, Rio de Janeiro.

Maillat, D.(1995) Milieux innovateurs et dinamique territoriale. In: Ralet, A. et Torre, A. (Hrsg): Economie industrielle et economie spaciale. Paris: [Economica], 211 -232.

Menezes, E.C. de O.(2009) Industrialização e meio ambiente no estado de Santa Catarina: estudo de caso sobre a evolução e os impactos socioambientais do segmento têxtil vestuarista na microrregião do Alto Vale do Itajaí. 2009. 317 f. Tese (Doutorado em Sociologia Política) - Programa de Pós-graduação em Sociologia Política. Florianópolis: UFSC.

Menezes, E. C. de O., Vieira, P.H. F. (2010) Aglomeração industrial e meio ambiente em debate: o caso do segmento têxtil-vestuarista da microrregião do Alto Vale do Itajaí - Santa Catarina. Revista Política \& Sociedade, 9(11), 225-255.

Menezes, E. C. de O., Sperb, M. P., Tonet, R. S.(2011) Elementos de la economía social en las comunidades de pescadores litoraleños (caiçaras): estudio de los municipios del Delta del Río Itajaí, SC, Brasil. Congreso de Economía Social, 3. Valladolid, abr.

Menezes, E. C. de O.(2011) Cooperativismo e desenvolvimento territorial sustentável: orientações estratégicas e alternativas de geração de trabalho e renda das comunidades pesqueiras da Grande Florianópolis - Santa Catarina. Relatório Pós-doutorado (Pós-doutorado em Administração) - Universidade Federal de Santa Catarina. Florianópolis: UFSC.

Milani, C. R. S.(2008) O princípio da participação social na gestão de políticas públicas locais: uma análise de experiências latino-americanas e europeias. In: Revista de Administração Pública. Rio de Janeiro, maio/jun.

MPA.(2011) Mais pesca e aquicultura. Recuperado em: fev. 2011, de: <http://www.mpa.gov.br/\#planos_e_politicas/mais-pesca-aquicultura>.

MPA.(2010) Dados registros de pesca e perfil dos pescadores artesanais da Grande Florianópolis. Dados estatísticos. Florianópolis: [s.n.]. (mimeo)

Morin, E.(1990) Introdução ao pensamento complexo. Lisboa: Instituto Piaget.

Ostrom, Elinor. (1990) Governing the commons: the evolution of institutions for collective action. New York: Cmbridge University Press.

Ostrom, E.(2010) Gouvernance des biens communs: pour une nouvelle approche des ressources naturelles. Paris : De Boeck.

Ouriques, H. R.(2007) Turismo em Santa Catarina: notas sobre o mercado de trabalho do setor. Chapecó: Unochapecó. Cadernos de Economia. Ano 11, (21), jul/dez.

Pecqueur, B.(2006) A guinada territorial da economia global. Eisforia: desenvolvimento territorial sustentável: conceitos, experiências e desafios teórico-metodológicos. Florianópolis: PPGAGR, 4, n. especial, dez. 
Pimentel, T. D. el al. (2010) Governança territorial como estratégia de gestão social do desenvolvimento. In: Ferreira, M.A. M., Emmendoerfer, M. L., Gava, R. Administração pública, gestão social e economia solidária: avanços e desafios. Viçosa: Emapegs/PGS.

Putnam, R. D.(2002) Comunidade e democracia: a experiência da Itália moderna. Rio de Janeiro: Editora $\mathrm{FGV}(3 . \mathrm{Ed})$.

Rais.(2010) Dados do número de empresas e emprego divisão CNAE 2000. Recuperado em dez.2010, de: $<$ http://sgt.caged.gov.br/XOLAPW.dll/fsmMain?C=false\&D=false>.

Rebouças, G. N. M.(2008) Regimes de apropriação, usos e conflitos de uso do espaço marinho e seus recursos: estudo de caso no município de Garopaba, litoral centro-sul de Santa Catarina. Paraná, 2008. 222 f. (Dissertação de Mestrado) - Programa de Pós-Graduação em Sistemas Costeiros e Oceânicos, UFPR.

Sabourin, E.(2010) Manejo dos recursos comuns e reciprocidade: os aportes de Elinor Ostrom ao Debate. Sustentabilidade em Debate. Brasília: Universidade Federal de Brasília, 1(2), dez.

Sachs, I.(1986) Ecodesenvolvimento: crescer sem destruir. São Paulo: Vértice.

.(2007) Rumo à ecossocioeconomia: teoria e prática do desenvolvimento. São Paulo: Cortez.

.(1992) Ecodesenvolvimento: 1972-1992. In: Agricultura e Meio Ambiente. Rio de Janeiro:

Universidade Federal do Rio de Janeiro. Ano 1(1).

. (1993) Estratégias de transição para o século XXI: desenvolvimento e meio ambiente. São Paulo: Studio Nobel e Fundap.

Sánchez, L. E.(2006) Avaliação de impacto ambiental: conceitos e métodos. São Paulo: Oficina de textos.

Schmitz, H.(1997a) Collective efficiency and increasing returns. IDS Working, 50, Mar.

.(1997b) Eficiência coletiva: caminho para o crescimento da indústria de pequeno porte. Ensaios FEE. Porto Alegre: FEE, 18(2), 164-200.

Silva, L. G. S. da.(1998) História e meio ambiente: a pequena pesca marítima no Brasil. Revista de Sociologia e Política, Curitiba, 10/11, 219-231.

Vieira, P. F.(2006) Rumo ao desenvolvimento territorial sustentável: esboço de roteiro metodológico participativo. Eisforia: desenvolvimento territorial sustentável: conceitos, experiências e desafios teóricometodológicos. Florianópolis, 4, n. especial, dez.

Data da submissão: 03/06/2015

Data da publicação: 30/04/2016 